\title{
Biological Effects of Vinyl Chloride: An Experimental Study
}

\section{by M. Winell," B. Holmberg," and T. Kronevi ${ }^{\dagger}$}

Plasma activities of alkaline phosphatase, (AP), transaminases and total lactate dehydrogenase (LDH) with isoenzymes were determined in mice inhaling 50 and 550 ppm vinyl chloride (VC). The animals were also autopsied and the tissue pathology was studied.

The total LDH activity was elevanted in both dose groups along with a shift to cathodic enzymes. AP was increased in animals exposed to $500 \mathrm{ppm}$ and transaminases were not at all changed. Enzyme changes occurred after the appearance of tumors.

Alveologenic adenomas occurred in all animals at the higher dosage and in about half of the animals inhaling the lower dose. Subperitoneal and subcutaneous hemangiosarcomas were frequent in both dose groups; but especially among 50 ppm animals. Only one animal had a hemangiosarcoma of the liver. No liver fibrosis was seen. All primary subperitoneal and subcutaneous tumors were located in fat tissue. Telangiectasis was observed in two animals in the $500 \mathrm{ppm}$ series. The importance of blood vessel changes in the toxicology of vinyl chloride is discussed.

\section{Introduction}

Among other toxicological effects (1), vinyl chloride (VC) has been found to induce liver injury in exposed workers (2) and has also been demonstrated to be an experimental (3, 4) and a human carcinogen $(5,6)$. Although a few studies on experimentally induced liver injury after chronic exposure to VC have been made, no attemnt has been made to investigate both biochemical and histopathological parameters in mice. The aim of the present toxicological study was to investigate possible changes in plasma enzymes and at the same time the histopathology of laboratory mice exposed to VC.

\section{Design of Study}

Groups of mice of an outbred albino commercial strain (NMRI strain) were exposed by inhalation from 12 weeks of age to 50 and $500 \mathrm{ppm}$ VC, $6 \mathrm{hr}$ day, 5 days/week. Each group consisted of 12 females and 12 males.

\footnotetext{
* Section of Occupational Toxicology Department of Occupational Medicine, National Board of Occupational Safety and Health, S-100 26 Stockholm, Sweden.

$\dagger$ National Veterinary Institute, S-104 05 Stockholm, Sweden.
}

The 50 ppm group was exposed for 52 weeks and the 500 ppm group for 26 weeks. A control group of 24 females and 24 males was exposed to air only. The animals were observed during their life time.

The plasma activities of the following enzymes were analyzed in an LKB 8600 reaction rate analyzer at $37^{\circ} \mathrm{C}$. Alkaline phosphatase (AP) was measured on $20 \mu$ plasma according to Bessey et al. ( 7$)$, except that 4-amino-2methyl-1-propanol was used as buffer as recommended by Morgenstern et al. (8).

Glutamic-oxalacetic transaminase (GOT) was measured according to Karmen et al. (9), and the activity of glutamic-pyruvic transaminase (GPT) according to Wroblewski and La Due (10) on $25 \mu$ l plasma.

Lactate dehydrogenase ( $\mathrm{LDH})$ was measured on $20 \mu \mathrm{l}$ plasma as described by Wroblewski and La Due (11), except that the $\mathrm{pH}$ was 7.4 in our study.

The isoenzymes of $\mathrm{LDH}$ were separated by disc electrophoresis and measured according to the method of Dietz and Lubrano (12). Plasma samples were diluted with a suitable volume of $40 \%$ sucrose, depending on the total $\mathrm{LDH}$ activity, in order to obtain an $\mathrm{LDH}$ activity of around $200 \mathrm{mU} / \mathrm{ml}$ in the sample. A $10 \mu \mathrm{l}$ portion of the diluted sample was added to the 
electrophoresis tube. The stained gels were evaluated at $550 \mathrm{~nm}$ in a Philip Unicam spectrophotometer equipped with a gel scanner.

In all groups, four animals of each sex were taken for pathological examination after 26 weeks of exposure, and in the control group another group was examined 52 weeks after the start of the experiment. The remaining animals were autopsied when moribund or when death occurred.

\section{Plasma Enzyme Changes}

The transaminases were not significantly elevated in exposed animals at any time during the experiment. The AP activity in animals exposed to $50 \mathrm{ppm}$ did not differ from normal values, but the $500 \mathrm{ppm}$ group had an elevated AP activity 46 weeks after the beginning of exposure (Fig. 1).

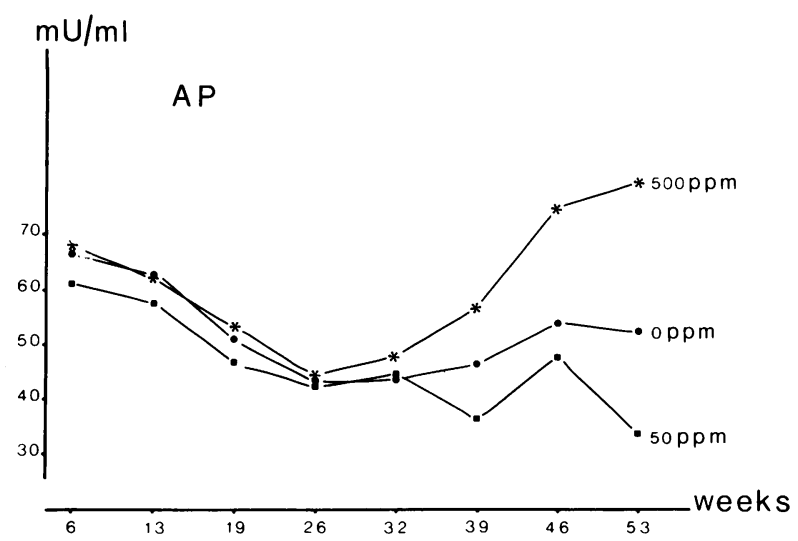

Figure 1. Alkaline phosphatase (AP) activity in plasma of exposed and control mice during one year. Exposure time 52 weeks $(50 \mathrm{ppm})$ and 26 weeks $(500$ ppm). The AP activity is significantly elevated $(p<0.05)$ in the 500 ppm group at week 46 . Each point represents mean values of one determination of each animal.

At 39 weeks the 500 ppm group showed significantly elevated total $\mathrm{LDH}$ activity, as later did the animals exposed to $50 \mathrm{ppm} \mathrm{VC}$ (Fig. 2). The increase in $\mathrm{LDH}$ in both groups was generally accompanied by a shift toward cathodic isoenzymes as measured by the percentage of the $M$ form (Fig. 3).

\section{Pathology}

The details of the morphological findings in this study are to be published elsewhere (13).

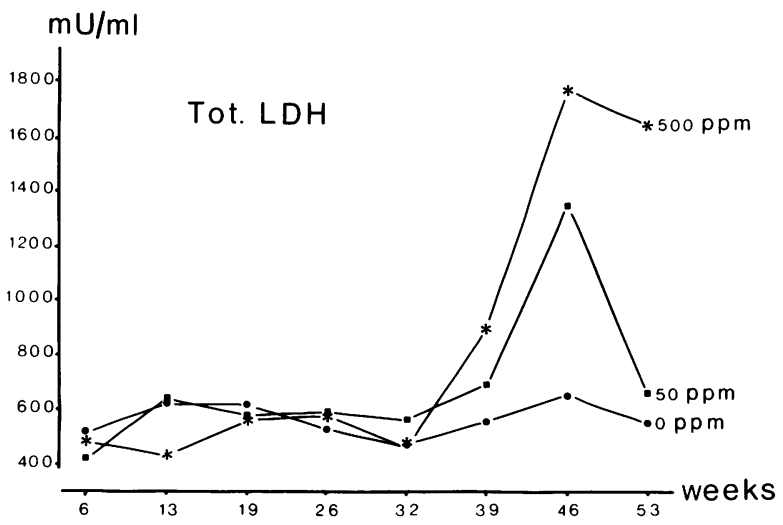

Figure 2. Total LDH activity in plasma of exposed and control mice during one year. Exposure time 52 weeks $(50 \mathrm{ppm})$ and 26 weeks $(500 \mathrm{ppm})$. The LDH activity is significantly elevated in the $500 \mathrm{ppm}$ group at 39 weeks $(p=0.001)$ and in the $50 \mathrm{ppm}$ group at 46 weeks $(p<0.001)$. Each point represents mean values of one determination on each animal.

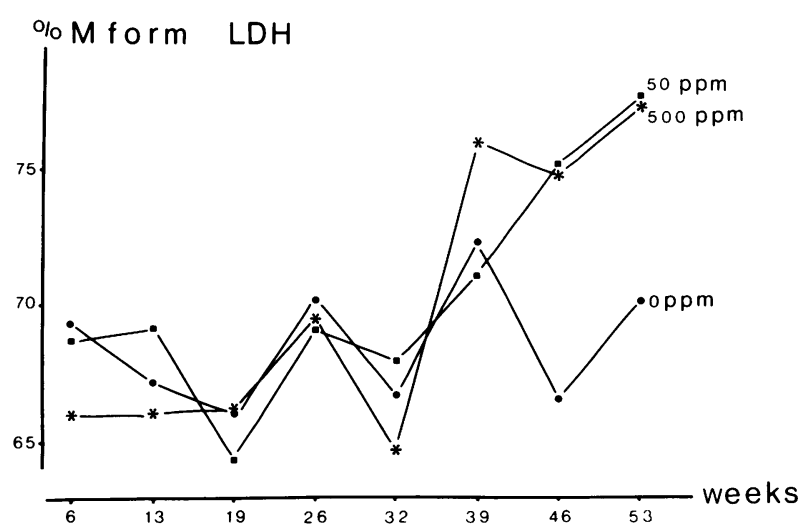

Figure 3. Percentage of $M$ form of $L D H$ isoenzyme pattern in plasma of control and exposed mice during one year. The $M$ form is significantly elevated in the 500 ppm group from 46 weeks $(p<0.001)$ and in the $50 \mathrm{ppm}$ group from 46 weeks $(p=0.001)$ compared to control.

Some morphological results are summarized in Tables 1 and 2.

In the control group three animals showed spontaneous tumors, namely, one mammary adenocarcinoma with pulmonary metastases, one disgerminoma of the ovary, and one reticulum cell sarcoma of spleen and mesenteric lymph nodes, all 45 weeks after the start of the experiment. 
Table 1. Number of animals with tumors 6 months after start of exposure.

\begin{tabular}{lcccc}
\hline & \multicolumn{3}{c}{ Number of animals with tumors } \\
\cline { 2 - 5 } $\begin{array}{c}\text { VC ex- } \\
\text { posure, } \\
\text { ppm }\end{array}$ & $\begin{array}{c}\text { Lung } \\
\text { adenomas }\end{array}$ & $\begin{array}{c}\text { Hemangio- } \\
\text { sarcomas }\end{array}$ & $\begin{array}{c}\text { Tother } \\
\text { tumors }\end{array}$ & $\begin{array}{c}\text { number of } \\
\text { animals } \\
\text { autopsied }\end{array}$ \\
\hline 0 & 0 & 0 & 0 & 8 \\
50 & 2 & 0 & 0 & 8 \\
500 & 8 & 0 & 1 a & 8 \\
\hline
\end{tabular}

'Mammary adenocarcinoma.

Table 2. Number of animals with tumors 12 months after start of exposure.

\begin{tabular}{lcccc}
\hline & \multicolumn{3}{c}{ Number of animals with tumors } \\
\cline { 2 - 5 } $\begin{array}{c}\text { VC ex- } \\
\text { posure, } \\
\text { ppm }\end{array}$ & $\begin{array}{c}\text { Lung } \\
\text { adenomas }\end{array}$ & $\begin{array}{c}\text { Hemangio- } \\
\text { sarcomas }\end{array}$ & $\begin{array}{c}\text { Total } \\
\text { Other } \\
\text { tumors }\end{array}$ & $\begin{array}{c}\text { number of } \\
\text { animals } \\
\text { autopsied }\end{array}$ \\
\hline 0 & 0 & 0 & $3^{\text {a }}$ & 24 \\
50 & 13 & $14^{\text {b }}$ & $2^{\text {c }}$ & 24 \\
500 & 24 & $8^{\text {d }}$ & $5^{-}$ & 24 \\
\hline
\end{tabular}

a One mammary adenocarcinoma, one disgerminoma of the ovary, and one reticulum cell sarcoma of the spleen and mesenteric lymph nodes.

b Subperitoneal and subcutaneous and pulmonary hemangiosarcomas.

c Mammary adenocarcinoma and one rhabdomyosarcoma.

d Subperitoneal, subcutaneous, hepatic, and renal hemangiosarcomas.

- Mammary adenocarcinomas and one kidney adenoma.

In the lower dose group about half the animals had alveologenic adenomas; two mice of this group were sacrified 26 weeks after the start of exposure. In animals autopsied between weeks 29 and 56, subperitoneal hemangiosarcomas occurred in pararenal (Fig. 4 and 5) and paraintestinal sites, and in the pelvic/caudal part of the abdominal cavity as well as in brown fat or other subcutaneous tissues. The mean latency time for tumor death was 46 weeks. Ruptures of hemangiosarcomas causing hemocoelia occurred in about one third of the exposed animals in the lower dose group.

All mice in the $500 \mathrm{ppm}$ group had alveologenic adenomas (Fig. 6). Also in this dose

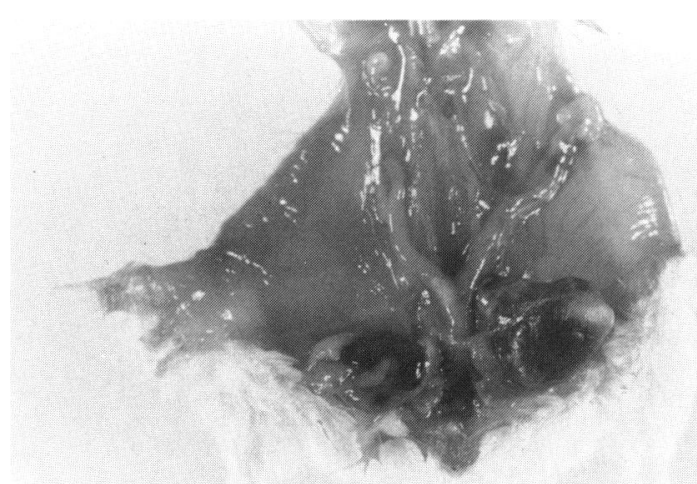

Figure 4. Hemangiosarcoma embedded in fat tissue is seen on each side of the uterus of animal exposed to $50 \mathrm{ppm}$ VC.

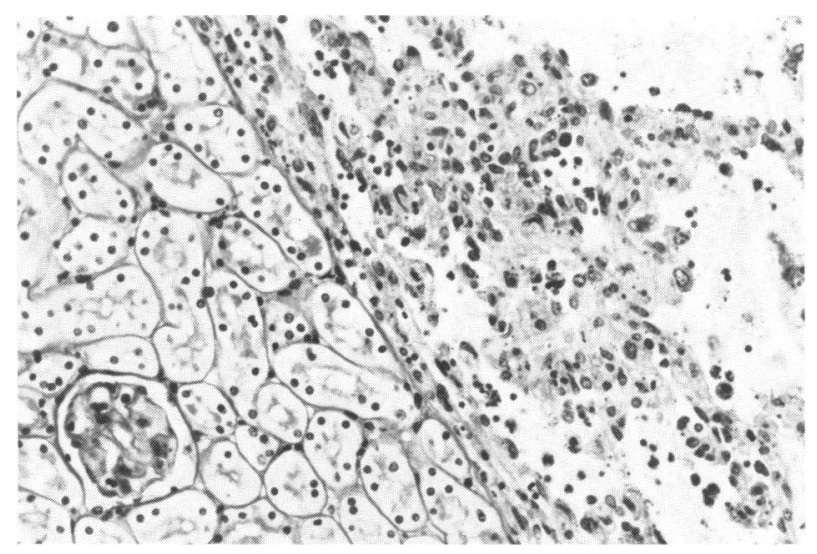

Figure 5. Pararenal hemangiosarcoma of an animal exposed to $50 \mathrm{ppm} \mathrm{VC.} \mathrm{The} \mathrm{tumor} \mathrm{tissue} \mathrm{is} \mathrm{well} \mathrm{sep-}$ arated from kidney tissue. PAS; $171 \times$.

group subperitoneal hemangiosarcomas were found in the pelvic/caudal part of the abdominal cavity although substantially fewer animals were bearing these tumors. Mammary adenocarcinomas were found in four animals. Only one animal had a hemangiosarcoma of the liver (Fig. 7). The mean latency time for tumor death was 35 weeks in this dose group. In two mice in the $500 \mathrm{ppm}$ group blood vessel dilatation (telangiectasis) was found in the liver (Fig. 8) without any other pathological liver changes.

All primary subcutaneous and subperitoneal hemangiosarcomas were located in fat tissue in both exposed groups. No liver fibrosis was noticed in any mouse. 


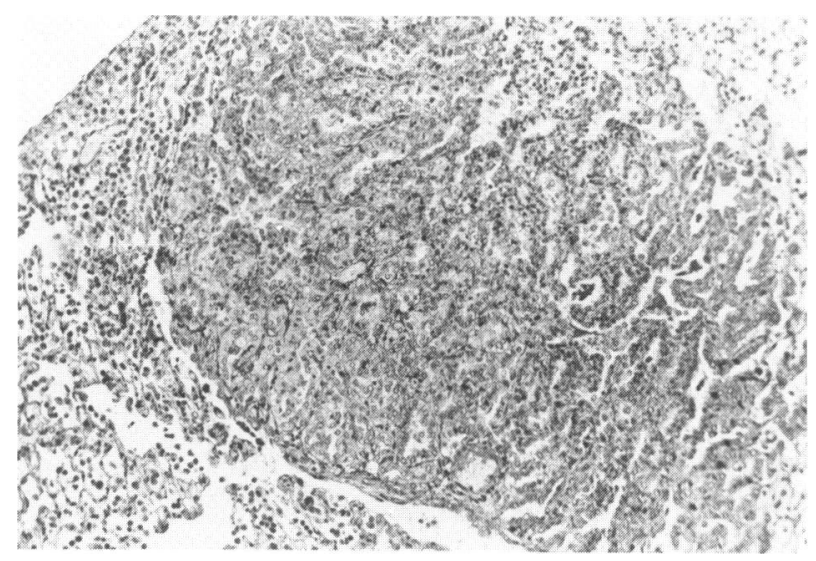

Figure 6. Alveologenic adenoma of an animal exposed to $50 \mathrm{ppm}$ VC. $\mathrm{H} \& \mathrm{E} ; 171 \times$.

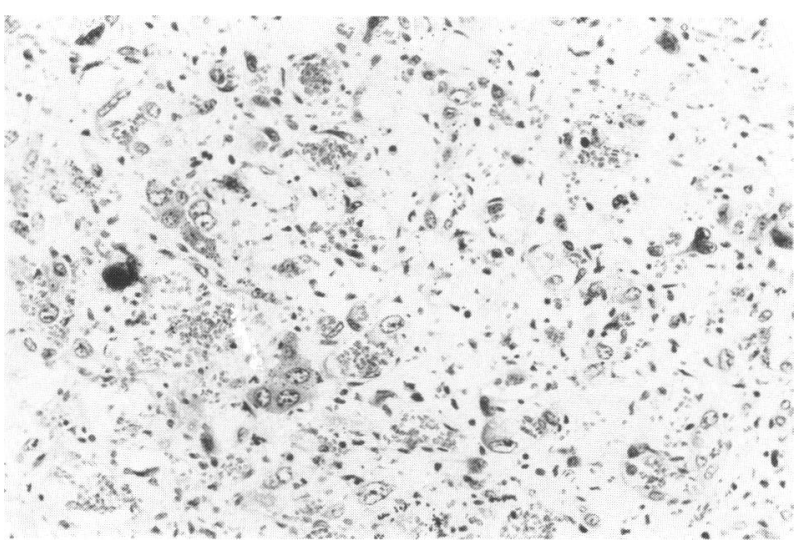

Figure 7. Liver of an animal exposed to $500 \mathrm{ppm} \mathrm{VC}$ showing hemangiosarcoma. H \& E; $134 \times$.

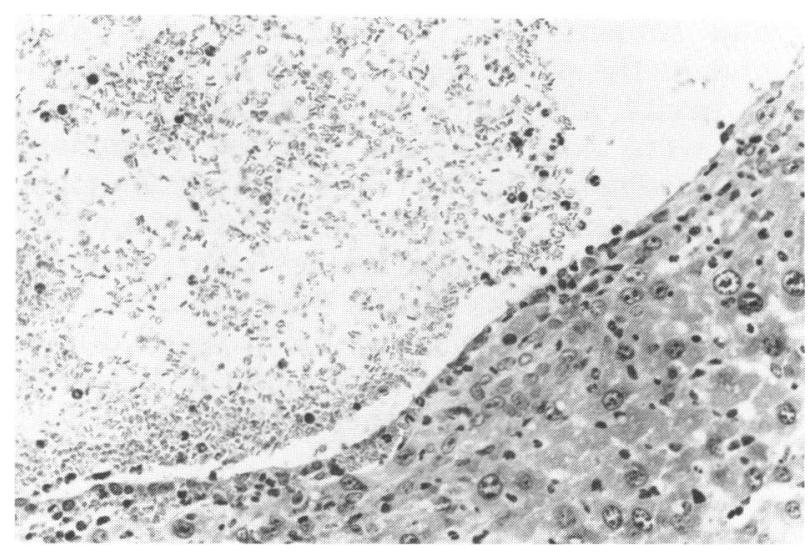

Figure 8. Liver telangiectasis of an animal exposed to $500 \mathrm{ppm}$ VC. $\mathrm{H} \& \mathrm{E} ; 171 \times$

\section{Discussion}

Changes in total plasma LDH enzyme activity can have several causes, such as increased physical stress (14), tissue necrosis due to disease or chemically induced organ damage $(15,16)$, or tumor growth $(17)$. In connection with irreversible injury, cells are releasing intracellular material including $\operatorname{LDH}(18,19)$, which may result in an elevation of total plasma $\mathrm{LDH}$ and/or an isoenzyme shift sometimes characterizing the organ damaged. Added to that, malignant cells leak small proteins (20) and may thus possibly contribute to a change in the total plasma LDH activity. A shift towards tho $\mathbf{M}$ form in the LDH-isoenzyme pattern has been observed, for instance, in monkeys exposed to carbon tetrachloride (21) and in rats exposed to chlorinated pesticides (22). The isoenzyme shift in malignant exudates is usually cathodic of nature (23), but the isoenzyme distribution of plasma $\mathrm{LDH}$ of cancer patients seems not to be a good diagnostic tool for detecting malignancy (24).

In the present experiments total $\mathrm{LDH}$ was elevated in both exposed groups of animals. A tendency to a dose-effect relationship in the elevation of total LDH but not in the percentage of $M$ form was seen. It is also interesting to note that a change in $\mathrm{LDH}$ activity occurred long after the first appearance of tumors, benign or malign, in both exposed groups. The increase in percentage of $M$ form in the $\mathrm{LDH}$ isoenzyme pattern suggests a liver injury. There was, however, no elevation in transaminase activities, which could serve as a further indication on liver injury.

AP normally decreases with increasing age of the animal (25). An increase in AP activity indicates among other things, lesions in the hepatobiliary tract (26) and has been observed in VC-exposed workers (27). Only those animals exposed to $500 \mathrm{ppm}$ showed a significant increase in AP activity.

The joint biochemical data indicate a tissue damage in mice caused by VC although the data are not convincingly indicative of liver injury. Changes in plasma enzymes in VCexposed mice seem furthermore not to be a good diagnostic criterion of tissue injury or early malignancy, as pathological lesions are manifest long before a deviation from normality in enzyme activity is noticed (28). 
Hemangiosarcomas of the abdominal sites seem often to have ruptured leading to death in hemocoelia. The blood vessels may thus have been fragilized during tumor induction or growth. In two animals inhaling $500 \mathrm{ppm}$ blood sinus dilatation in the liver was seen without any other pathological liver change. In studies made on exposed workmen the blood vessels are involved as a target organ for vinyl chloride in the development of acroosteolysis and of Raynaud's phenomenon as well as it is reflected in an overrepresentation of deaths in circulatory diseases among VC/PVC workers as reported in this symposium (29). One may thus conclude that blood vessel changes are part of the socalled vinyl chloride syndrome, including tumor disease-or may even be a step in the development of malignant tumor disease induced by this chemical (30).

This work was supported by the Swedish Work Environment Fund, Stockholm.

\section{REFERENCES}

1. Holmberg, B., and Molina, G. The industrial toxicology of vinyl chloride. A review. Work-Environm.-Health 11: 138 (1974).

2. Marsteller, H. J., et al. Chronisch-toxische Leberschäden bei Arbeitern in der PVC-Produktion. Deutsch. Med. Wochenschrift 98: 2311 (1973).

3. Viola, P. L., Bigotti, A., and Caputo, A. Oncogenic response of rat skin, lungs and bones to vinyl chloride. Cancer Res. 31: 516 (1971).

4. Maltoni, C. The value of predictive experimental bioassays in occupational and environmental carcinogenesis. An example: vinyl chloride. Ambio 4: 18 (1975).

5. Lloyd, J. W. Angiosarcoma of the liver in vinyl chloride/polyvinyl chloride workers. J. Occup. Med. 17: 333 (1975).

6. Byrén, D., and Holmberg, B. Two possible cases of angiosarcoma of the liver in a group of Swedish vinyl chloride-polyvinyl chloride workers. Ann. N.Y. Acad. Sci. 246: 249 (1975).

7. Bessey, O. A., Lowry, O. H., Brock, M. J. A method for the rapid determination of alkaline phosphatase with five cubic millimeters of serum. J. Biol. Chem. 164: 321 (1946).

8. Morgenstern, et al. An automated $p$-nitrophenylphosphate serum alkaline phosphatase procedure for the autoanalyzer. Clin. Chem. 11: 876 (1965).

9. Karmen, A., A note on the spectrophotometric assay of glutamic-oxalacetic transaminase in human blood serum. J. Clin. Invest. 34: 131 (1955).

10. Wroblewski, F., and La Due, J. S. Serum glutamic pyruvic transaminase in cardiac and hepatic disease. Proc. Exp. Biol. Med. 91: 569 (1956).
11. Wroblewski, F., and La Due, J. S. Lactic dehydrogenase in blood. Proc. Soc. Exp. Biol. Med. 90: 210 (1955).

12. Dietz, A. A., and Lubrano, T. Separation and quantitation of lactic dehydrogenase isoenzymes by disc electrophoresis. Anal. Biochem. 20: 246 (1967).

13. Kronevi, T., Holmberg, B., and Winell, $M$. The pathology of vinyl chloride exposed mice. Acta. Vet. Scand. 17: 328 (1976).

14. Porter, H., Doty, D. H., and Bloor, C. M. Interaction of age and exercise on tissue lactic dehydrogenase activity in rats. Lab. Invest. 25: 572 (1971).

15. Muggli, A. LDH-Isoenzyme in der Diagnose des Herzinfarktes. Vergleichende Untersuchungen mit Cellegelelektrophorese, DEAE-Sephadex and HBDH-Bestimmung. Enzymol. Biol. Clin. 9: 401 (1968).

16. Ringoir, S. LDH isoenzyme pattern of rat kidney in mercurial intoxication. Nephron 7: 538 (1970).

17. Burgess, E. A., and Sylvén, B. Lactic dehydrogenase activity in plasma and interstitial fluid during growth of mouse tumors. Cancer Res. 23: 714 (1963).

18. Holmberg, B. On the permeability to lissamine green and other dyes in the course of cell injury and cell death. Exp. Cel Res. 22: 40 (1961).

19. Vacca, C. Possibility that different "stresses", and especially hypoxia, allow the outspread of intracellular enzymes, due to an increase of cell membrane permeability, without tissue necrosis. Riv. Med. Aero 26: 443 (1963).

20. Holmberg, B. On the in vitro release of cytoplasmic enzymes from ascites tumor cells as compared with strain L cells. Cancer Res. 21: 1386 (1961).

21. Wieme, R. J., and Maercke, Y. The fifth (electrophoretically slowest) serum lactic dehydrogenase as an index of liver injury. Ann. N.Y. Acad. Sci. 94: 898 (1961).

22. Khaikina, B. I., Kuzminskaya, U. A., and Alekhina, S. M. Effect of some pesticides on activity of isoenzymes of serum lactate dehydrogenase. Bull. Exptl. Biol. Med. (USSR), 70: 1140 (1970).

23. Richterich, R., and Burger, A. Lactic dehydrogenase isoenzymes in human cancer cells and malignant effusions. Enzymol. Biol. Clin. 3: 65 (1963).

24. Kowalewski, S. L. Die Isoenzyme der Lactatdehydrogenase. Thieme Verlag, Stuttgart, 1972.

25. Schmidt, F. H. Experiences with enzyme determinations in toxicity studies. In Proceedings of the European Society for the Study of Drug Toxicity. Vol. V. Bad Homberg, 1965. (Adv. Toxicological Methodology), Excepta Medica Foundation, 1965, p. 97.

26. Popper, H., Koch-Weser, D., and Huerga, J. Serum and hepatic enzymes in experimental liver damage. J. Mount Sinai Hosp. 19: 256 (1952).

27. Lilis, R., et al. Liver function among 1177 vinyl chloride polymerization workers. Abstracts of the XVIII International Congress on Occupational Health, Brighton, England, Steptember 1975: p. 398.

28. Grice, H. C., et al. Correlation between serum enzymes, isozyme patterns and histologically detec- 
table organ damage. Food Cosmet. Toxicol. 9: 847 (1971).

29. Byrén, D., et al. Mortality and cancer morbidity in a group of Swedish VCM/PVC production workers.

Environ. Health Perspect. 17: 167 (1976).
30. Thomas, L. B., and Popper, H., Pathology of angiosarcoma of the liver among vinyl chloride-polyvinyl chloride workers. Ann. N.Y. Acad. Sci. 246: 268 (1974). 